\title{
Analysis of Anesthesia Administration in the Endoscopy Unit in Terms of Patient Profile and Complications: Retrospective Study
}

\author{
Endoskopi Ünitesinde Anestezi Uygulamalarının Hasta Profili ve \\ Komplikasyonlar Açısından Analizi: Retrospektif Çalışma
}

\author{
Harun UYSAL ๑, Hayrettin DAŞKAYA ๑
}

\begin{tabular}{l|l} 
Ethics Committee Approval: This study approved by the Non-invasive Clinical Trials Ethics Com- & $\begin{array}{l}\text { Cite as: Uysal H, Daskaya H. Analysis of anesthesia administration in the endoscopy } \\
\text { mittee of Bezmialem Vakif University, } 22 \text { July } 2019,16 / 312\end{array}$ \\
Conflict of interest: The authors declare that they have no conflict of interest. & J. 2019;34:278-83. \\
Funding: None. & \\
Informed Consent: Not Applicable. &
\end{tabular}

\begin{abstract}
Objective: This study aimed to analyze patients undergoing endoscopic interventions in terms of comorbid diseases, preoperative anesthesia management predictions, intraoperative-postoperative complications and requirements for intensive care.

Method: Records of patients who underwent procedures under anesthesia in the endoscopy unit were retrospectively screened. The patients' preoperative anesthesia evaluation, intraoperative anesthesia, and postoperative recovery data and intensive care monitoring requirements were recorded. The data obtained were analyzed statistically.

Results: It was identified that the preoperative risk prediction of patients was statistically significant for intraoperative and postoperative monitoring. Comorbid disease and high age were determined to increase the requirements for intensive care after the procedure. Increased need for qualified admission was determined in patients with desaturation and hypotension. Conclusion: A prerequisite for reliable administration of anesthesia is having detailed information about the patient and being prepared for possible complications. When examined from this aspect, analysis of the patient profile undergoing procedures in the endoscopy unit is important. In our study, we revealed the presence of elderly patients and comorbid disease(s) in the patient group who underwent procedures in this unit. The need for detailed preliminary evaluation of the patients undergoing these types of procedure and requirements for intensive care after the procedure, if necessary, should definitely be considered.
\end{abstract}

Keywords: Endoscopic interventions, outpatient anesthesia, perioperative care

öz

Amaç: Bu çalışmada endoskopik girişim yapılan hastaların; ek hastalık varlığı, preoperatif anestezi yönetimi öngörüsü, intraoperatif-postoperatif komplikasyon ve yoğun bakım gereklilikleri açısından analizi amaçlanmıştır.

Yöntem: Endoskopi ünitesinde anestezi altında işlem uygulanan hastaların kayıtları geriye yönelik tarandı. Hastaların preoperatif anestezi açısından değerlendirmeleri, intraoperatif anestezi verileri, postoperatif derlenme verileri ve yoğun bakım takibi gerekliliği kaydedildi. Elde edilen veriler istatistiksel analize tabi tutuldu.

Bulgular: Hastaların preoperatif risk öngörüsünün intraoperatif ve postoperatif takipte istatistiki anlama sahip olduğu olduğu tespit edildi. Ek hastalık ve yüksek yaş mevcudiyetinin işlem sonrası yoğun bakım gerekliliğini artırdığı tespit edildi. Desatürasyon ve hipotansiyon gözlenen hastalarda nitelikli yatış gerekliliğinin arttı̆ı̆ tespit edildi.

Sonuç: Güvenli anestezi uygulamanın ön koşulu; hasta hakkında detaylı bilgi sahibi olmaktan ve olası komplikasyonlara hazırlıkı olmaktan geçmektedir. Bu açıdan bakıldığında endoskopi ünitelerinde işlem uygulanan hasta profilinin analizi önem arz etmektedir. Çalışmamızda bu ünitelerde işlem uygulanan hasta grubunun yaşlı ve ek hastalık mevcudiyetini tespit ettik. Bu tür işlem uygulanacak hastalarda öncesinde ayrıntılı bir değerlendirme ve gerektiğinde işlem sonrası yoğun bakım takibi gerekliliği muhakkak göz önünde bulundurulmalıdır.

Anahtar kelimeler: Endoskopik girişimler, ameliyathane dışı anestezi, perioperatif bakım
Received: 22 July 2019

Accepted: 4 September 2019 Online First: 27 September 2019

Corresponding Author: H. Daskaya

ORCID: 0000-0002-0155-1387 Bezmialem Vakif University Faculty of Medicine, Department of Anesthesiology and Reanimation, Istanbul, Turkey h.daskaya@gmail.com

H. Uysal

ORCID: 0000-0003-0426-8525 Bezmialem Vakif University Faculty of Medicine, Department of Anesthesiology and Reanimation, Istanbul, Turkey 


\section{INTRODUCTION}

Endoscopic interventions, though initially used only as a diagnostic tool, have begun to be frequently used for therapeutic aims in recent periods. With this aim, drainage of pancreatic pseudocysts, treatment of cystic lesions in the pancreas, cholangiopancreatography accompanied by endoscopic ultrasonography (EUS), treatment of gastric varices, localized treatment for pancreas tumors and treatment of subepithelial lesions are being performed more and more frequently using endoscopic methods.

The ideal anesthesia method for endoscopic procedures is still controversial. This debate is due to the lack of standardization of significant numbers of procedures in terms of method, duration and degree of invasiveness, and the high comorbidity and age in the patient profile ${ }^{1}$. The quality of anesthesia administered may be different depending on the patient's comorbid disease status and possible complications.

This retrospective study analyzed the presence of comorbid disease(s), preoperative predictions about anesthesia management, intraoperativepostoperative complications and intensive care requirements of patients undergoing endoscopic interventions.

\section{MATERIAL and METHODS}

This study was approved by the Noninvasive Ethics Committee for Clinical Trials of Bezmialem Vakif University (22 July 2019, 16/312).

The study included patients who had undergone endoscopic procedures under anesthesia from 01.03.2019 to 30.06.2019 in the endoscopy unit by investigating patient files in the central database and written patient files. The files of these patients were retrospectively investigated. Patient's age, sex, preoperative comorbid diseases, type of comorbid disease(s), if any, type of gas- troenterological intervention to be performed, anesthesia method administered and complications occurring during administration, if any, were recorded. The duration of the procedure, total duration of stay in the postanesthesia care unit (PACU), and unexpected situations in the recovery unit, if any, were recorded. The preoperative anesthesia evaluation forms of the patients were screened and the number of patients with postoperative intensive care unit (ICU) requirements predicted before the procedure, and the numbers and types of these patients entering the ICU were noted. Additionally, patient discharge status after the procedure was investigated and noted.

For statistical analysis of the data obtained, SPSS 20.0 for Windows statistical program was used. Numerical data are given as mean \pm standard deviation (SD). For comparisons Student- t test and the Mann-Whitney $U$ tests were used. Chi-square and Fisher exact test were used for nonnumerical data. $p<0.05$ was accepted as the level of statistical significance.

\section{RESULTS}

The retrospective evaluation included 276 patients who had undergone procedures in the endoscopy unit under anesthesia during a 4-month period. Of cases, 129 were male (46.7\%) and 147 were female $(53.3 \%)$. Mean age of the cases was $58 \pm 14$ (19-87) years. The distribution of age, sex, body mass index (BMI), duration of procedure and PACU stay is shown in Table 1. Among comorbid diseases, hypertension (HT) was most commonly

Table 1. Demographic data for patients $(n=276)$.

\begin{tabular}{lllll}
\hline & Age & BMI & $\begin{array}{l}\text { Procedure } \\
\text { duration (min) }\end{array}$ & $\begin{array}{l}\text { PACU } \\
\text { duration (min) }\end{array}$ \\
\hline Mean & 59.4 & 27.8 & 28.4 & 27.2 \\
Std. Deviation & 14.6 & 5.2 & 15.2 & 13.2 \\
Median & 60.0 & 27.2 & 24.0 & 26.0 \\
Minimum & 19.0 & 18.2 & 10.0 & 5.0 \\
Maximum & 88.0 & 48.2 & 133.0 & 57.0
\end{tabular}

BMI: body mass index; PACU: postoperative recovery duration 


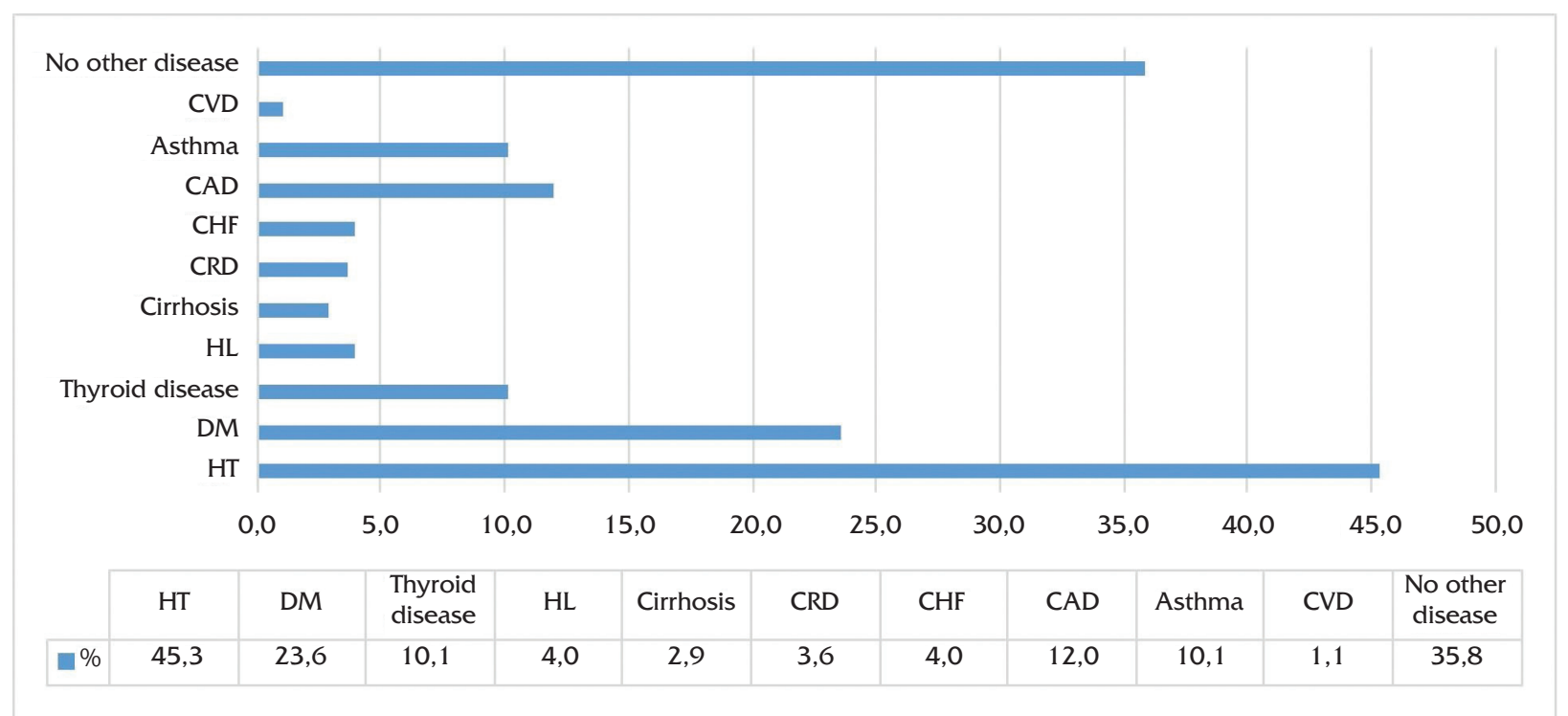

Figure 1. Comorbid disease distribution (percentage).

HT: hypertension, DM: diabetes mellitus, HL: hyperlipidemia, CRD: chronic renal disease, CHF: congestive heart failure, CAD: coronary artery disease, CVD: cerebrovascular diseases.

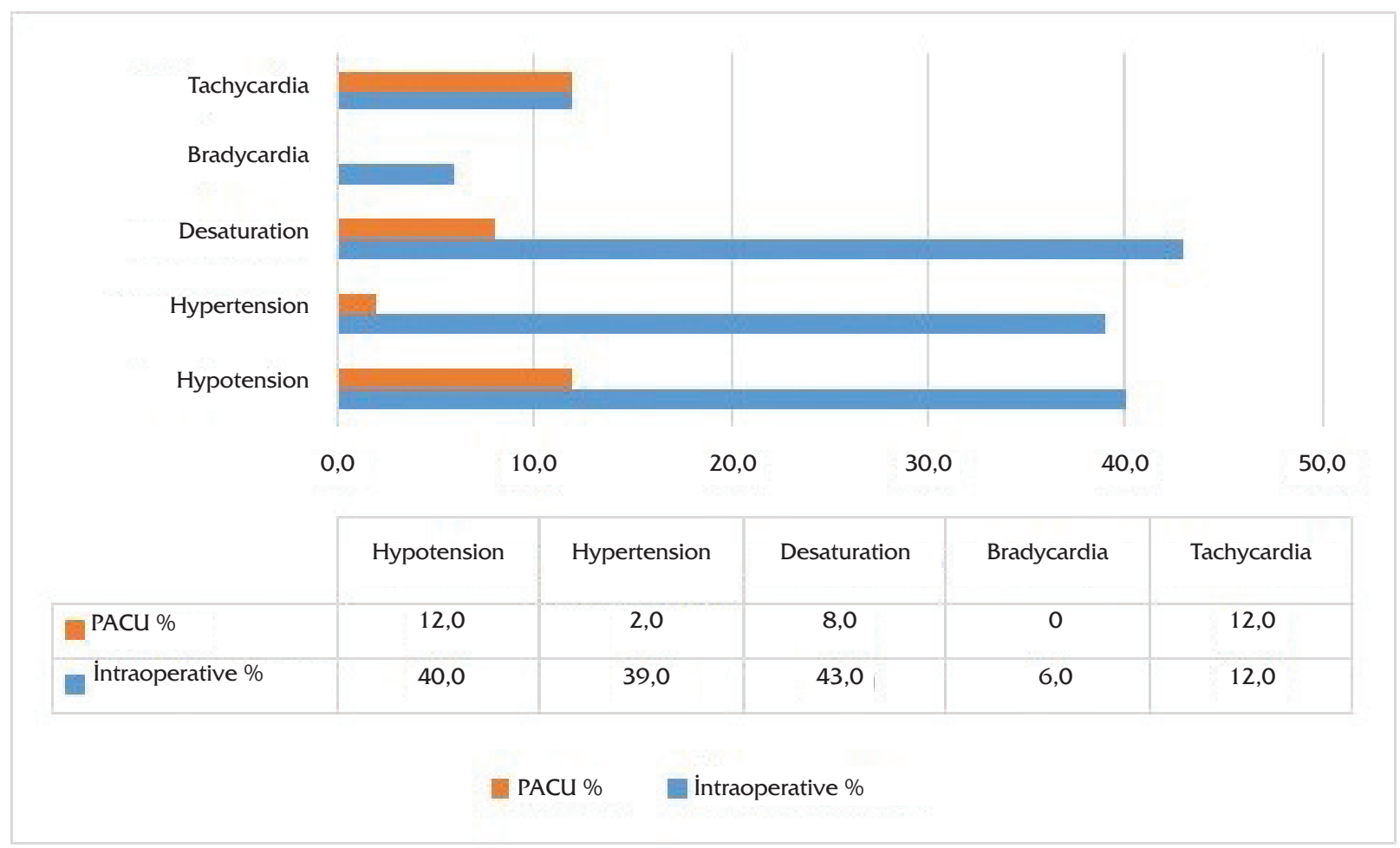

Figure 2. Perioperative complication distribution (percentage).

PACU: Postoperative care unite.

observed in $45.3 \%(n=125)$ of the patients. The proportional distribution of comorbid diseases is shown in Figure 1.
Patients had (64.2\%) or had not (35.8\%) any chronic disease. Endoscopic retrograde cholangiography (ERCP was performed in 29.4\%, 50.4\% 
EUS in $50.4 \%$, and EUS + ERCP in $20.2 \%$ of the patients. Complications and their intraoperative and postoperative frequencies are shown in Figure 2.

For $6.9 \%$ of cases $(n=19)$, the anesthesia clinic predicted that ICU would be required after the procedure. Before the procedure $30.8 \%$ of the patients were admitted in ICU , and $69.2 \%$ of these cases were outpatients. After the procedure, 38.4\% of cases $(n=106)$ were discharged home, 56.2\% $(n=155)$ of them were admitted to the ward and $5.4 \%(n=15)$ of them to ICU (Table 2$)$.

Table 2. Procedures and patient admission distributions.

\begin{tabular}{lll}
\hline Procedure type & n & Percentiles \\
\hline ERCP & 137 & 49,6 \\
EUS & 195 & 70,7 \\
EUS+ERCP & 56 & 20,2 \\
Indicated for preoperative ICU & 19 & 6,9 \\
Preoperative hospitalization & 85 & 30,8 \\
Postoperative discharge & 106 & 38,4 \\
Postoperative hospitalization & 155 & 56,2 \\
ERCP & 15 & 5,4 \\
\end{tabular}

ERCP: Endoscopic retrograde cholangiography, EUS: endoscopic ultrasonography, ICU: intensive care unit.

Statistically significant correlations existed between ICU requirements predicted preoperatively and ICU requirements after the procedure $(p<0.001)$. Eleven of 19 patients with ICU admission requirements predicted during preoperative evaluation of anesthesia were admitted to the ICU postoperatively. Four of 257 cases not considered to require ICU, had unpredicted ICU requirements.

There was a statistically significant relationship between the presence of chronic renal disease (CRD), congestive heart failure (CHF), coronary artery disease (CAD), asthma, and Alzheimer disease and postoperative ICU requirements $(p<0.005)$.

The most commonly observed intraoperative complication was desaturation detected in 15.6\% of the patients.
There was a statistically significant relationship between intraoperative development of hypotension, desaturation, bradycardia and tachycardia with postoperative ICU requirements $(p<0.001)$.

There was no statistically significant relationship between smoking and alcohol use with ICU requirements.

There was a very weak statistically significant ( $r: 0.185)$ correlation between age and duration of the procedure $(p=0.002)$. There was a positive correlation between duration of procedure and PACU stay $(p<0.001)$.

Post procedure ICU requirements were identified to be 34 times increased for CRD cases and 10 times increased for CAD cases.

\section{DISCUSSION}

With the increase in accessibility of health services in the modern age, there has been an increase in the number of interventional procedures performed in endoscopy units. Endoscopic procedures have increased in complexity and generally advanced endoscopic procedures have become an alternative to open surgery for patients with significant comorbidities. The importance of patient comfort and satisfaction during these procedures and the desire of endoscopists to perform procedures more reliably and with shared responsibility have increased the demand for administration of anesthesia by professional anesthesiologists in endoscopy units ${ }^{2}$. In 2017, in the United States of America alone over 50 million gastrointestinal (GI) endoscopic procedures were performed and the majority of these were realized under anesthesia ${ }^{3}$. For these types of procedures, professional anesthesiologists are asked to administer sedation or general anesthesia or perform sedated or unsedated monitoring of patients with significant comorbidities. Anesthesia management requires specific information, skills and equipment and good patient evaluation be- 
fore and after anesthesia. Knowing the profile and possible complications for patients who will undergo procedures in the endoscopy unit will be beneficial for the development of strategies before unwanted situations occur. Anesthesia for GI endoscopy may be associated with higher complication risks for anesthesia compared to many other procedures. The reasons for this correlation are multifactorial and probably involve the majority of these procedures performed outside the operation room, increasingly complicated procedures, and reality of administration of anesthesia in an outpatient setting ${ }^{4}$. Hypoxemia is the most common complication of anesthesia observed during GI endoscopy ${ }^{5,6}$. In our study, the most common complication was desaturation observed in 15.6\% of the patients.

When we analyzed our study data, the mean age of patients was seen to be $60( \pm 19)$ years. Considering this mean age, it can be said that anesthesia procedures in endoscopy units have shifted towards geriatric anesthesia administration. When a routine and uncomplicated gastroenterologic endoscopy procedure normally targeted to outpatients is performed under anesthesia, the patient may require transfer to the postoperative ICU. Because advanced age of the patients and presence of comorbid diseases (hyper-hypotension, heart diseases, DM, obesity, etc.) require for deep sedation or even general anesthesia with close hemodynamic monitoring. When examined from this aspect, the need for more detailed perioperative management is revealed.

Preliminary conditions for administration of anesthesia in outpatient setting are good analysis of the patient's medical status at first, then knowing the effect of the procedures to be performed in terms of anesthesia, and preparing the field of application equivalent to a surgical operating room $^{7-9}$. When we analyzed our study data, it was identified that a significant portion of patients undergoing this type of procedure had statistically significant levels of comorbid diseases. The iden- tified comorbidities were determined to be an important factor in postoperative ICU requirements. When examined from this aspect, patients undergoing endoscopic interventions should definitely be examined by an anesthesiologist beforehand and the need for risk analysis was to be investigated $^{10}$. Though, in our study we did not compare anesthesia for GI endoscopic interventions with administration of anesthesia in the operating room in terms of the incidence of complications, the complication rates especially, for upper gastrointestinal system interventions, were reportedly higher in the literature. In our study data, nearly $7 \%$ of patients were predicted to require ICU after the procedure, and the majority of these patients were transferred to the ICU after the procedure. Here the most important factors were observed to be comorbid disease and age.

A publication including analysis of malpractice accusations from 1999 to 2009 in the American Society of Anesthesiologists database showed that complications related to airway management were two times more common in administration of anesthesia outside the operating room and the most common specific event was insufficient oxygenation/ventilation ${ }^{11}$. It is difficult to interpret studies about complications of anesthesia for GI endoscopy because most complications are rare and the majority of the literature is retrospective or prospective predictive but not randomized. When unexpected situations before and after the procedure are analyzed in our study, events of newly developing hypertension, hypotension, tachycardia and bradycardia were observed to be associated with patient requirements for more advanced surveillance. When examined from this aspect, we believe that it is necessary to monitor patients developing these types of situations for longer periods.

\section{CONCLUSION}

The first prerequisites for reliable administration of anesthesia are knowing the patient well and 
administering the most appropriate anesthesia protocol. When examined from this aspect, analysis of the patient profile undergoing procedures in the endoscopy unit is important. In our study, we identified that this patient group was mainly older and had comorbid diseases. We observed that this situation caused vital complications. As a result, we think that the anesthesiologist has medicolegal responsibility to predict possible problems beforehand and should have complete information, skill and equipment preparation so as to reduce these problems. Additionally, we believe that there is a need for prospective randomized studies to predict risks.

\section{REFERENCES}

1. Daşkaya H, Uysal H, Çiftçi T, Baysal B, İdin K, Karaaslan K. Use of the gastro-laryngeal tube in endoscopic retrograde cholangiopancreatography cases under sedation/analgesia. Turk J Gastroenterol. 2016;27:246-51. [CrossRef]

2. Inadomi JM, Gunnarsson CL, Rizzo JA, Fang H. Projected increased growth rate of anesthesia professional-delivered sedation for colonoscopy and EGD in the United States: 2009 to 2015. Gastrointest Endosc. 2010;72:580-6. [CrossRef]

3. 75 Million Endoscopies Performed Annually According to iData Research Procedure Analysis. USA; 2018. Available from: https://idataresearch.com/75-million-endos- copies-performed-annually-according-to-idata-researchprocedure-analysis/

4. Goudra B, Nuzat A, Singh PM, Borle A, Carlin A, Gouda G. Association between Type of Sedation and the Adverse Events Associated with Gastrointestinal Endoscopy: An Analysis of 5 Years' Data from a Tertiary Center in the USA. Clin Endosc. 2017;50:161-9. [CrossRef]

5. Sharma VK, Nguyen CC, Crowell MD, Lieberman DA, de Garmo P, Fleischer DE. A national study of cardiopulmonary unplanned events after GI endoscopy. Gastrointest Endosc. 2007;66:27-34. [CrossRef]

6. Goudra B, Nuzat A, Singh PM, Gouda GB, Carlin A, Manjunath AK. Cardiac arrests in patients undergoing gastrointestinal endoscopy: A retrospective analysis of 73,029 procedures. Saudi J Gastroenterol. 2015;21:400-11. [CrossRef]

7. Iyilikci L, Çakmak S, Ogdul E, et al. Anesthesia experiences outside of the operating room. Turk J Anaesthesiol Reanim. 2006;34:169-6.

8. Türk Anesteziyoloji ve Reanimasyon Derneği (TARD) Anestezi Uygulama Kılavuzları. Ameliyathane Dışı Anestezi Uygulamaları 2015. Available from: https://www. tard.org.tr/assets/kilavuz/1.pdf (Accessed on 22 August 2019)

9. Guidelines guidelines for ambulatory anesthesia and surgery, American Society of Anesthesiologist. USA; 2018. Available from: https://www.asahq.org/standards-andguidelines/guidelines-for-ambulatory-anesthesia-andsurgery

10. Enestvedt BK, Eisen GM, Holub J, Lieberman DA. Is the American Society of Anesthesiologists classification useful in risk stratification for endoscopic procedures? Gastrointest Endosc. 2013;77:464-71. [CrossRef]

11. Metzner J, Posner KL, Domino KB. The risk and safety of anesthesia at remote locations: the US closed claims analysis. Curr Opin Anaesthesiol. 2009;22:502-8. [CrossRef] 